\title{
PENGARUH KUALITAS LAYANAN DAN HARGA TERHADAP KEPUASAN KONSUMEN MEMBELI DI J.CO DONUTS DAN COFFE PALU GRAND MALL
}

\author{
DEDE KURIANG LISTANTO \\ CHALIL \\ IRA NURIYA SANTI \\ Program Studi S1 Manajemen, Fakultas Ekonomi, Universitas Tadulako \\ email: dedek1379@gmail.com, Chalil_ah@yahoo.com, Ira_nuria@yahoo.com
}

\begin{abstract}
This study aims to know the influence of service quality and price to consumen satisfaction at J.CO Donuts and Coffe Palu Grand Mall. Total sample in this study are 60 respondent, with Purposive sampling as sampling technique. Data analysis methode used in this research is Multiple Linear Regression Analysis. The result shows that service quality and price simultaneously have a signifikan influnce to consument satisfaction at J.CO Donuts and Coffe Palu Grand Mall. Service quality partially have a signifikan influence to consument satisfaction at J.CO Donuts and Coffe Palu Grand Mall. Price partially have a signifikan influence to consument satisfaction at J.CO Donuts and Coffe Palu Grand Mall.
\end{abstract}

Keywords: Service quality, price, consumen satisfaction

\begin{abstract}
Abstrak
Tujuan dari penelitian ini yaitu untuk mengetahui pengaruh kualitas layanan dan harga terhadap kepuasan konsumen di J.CO Donuts dan Coffe Palu Grand Mall. Sampel yang digunakan penelitian ini yaitu sebanyak 60 responden, dengan teknik penarikan sampel yang digunakan adalah purposive sampling. Metode analisis data yang digunakan dalam penelitian ini adalah Regresi Linear Berganda. Hasil penelitian menunjukkan bahwa kualitas layanan dan harga secara serempak berpengaruh siginifikan terhadap kepuasan konsumen di J.CO Donuts dan Coffe Palu Grand Mall. Kualitas layanan secara parsial berpengaruh signifikan terhadap kepuasan konsumen di J.CO Donuts dan Coffe Palu Grand Mall. Harga secara parsial berpengaruh signifikan terhadap kepuasan konsumen di J.CO Donuts dan Coffe Palu Grand Mall.
\end{abstract}

Kata Kunci: Kualitas Layanan, Harga, Kepuasan Konsumen.

\section{PENDAHULUAN}

Seiring dengan perkembangan zaman dan meningkatnya taraf kehidupan masyarakat pada saat sekarang ini, maka sedikit banyak mempengaruhi pola konsumsi dan cara mereka dalam memenuhi kebutuhan. Sehingga menuntut para pelaku bisnis untuk berkompetisi dalam persaingan bisnis yang ketat seperti sekarang, jumlah merek dan produk baik barang maupun jasa yang bersaing di pasar menjadi sangat banyak sehingga konsumen memiliki ragam pilihan dan alternatif, khususnya dibidang jasa.

Perusahaan jasa berfungsi menciptakan pengalaman baru yang berkesan bagi konsumen (Lupiyoadi, 2013:120). Sehingga tujuan maupun pengalaman baru bagi konsumen merupakan suatu tantangan tersendiri bagi perusahaan jasa tersebut. Sebagian besar produk jasa yang abstrak dan tidak terwujud, mempunyai aspek yang berada disekitar inti perusahaan menjadi pertimbangan bagi konsumen.Salah satu aspek tersebut adalah lingkungan tempat penyampaian jasa tersebut berada (service scape).Ketatnya persaingan dan semakin meningkatnya ekspetasi konsumen terhadap sebuah produk, terkhusus produk jasa membuat perusahaan harus memiliki cara untuk meningkatkan proposisi nilai (value proposition).

Adisucipto (2010:187) menyatakan bahwa, konsumen membentuk harapan terhadap pelayanan dari suatu jasa. Pada dasarnya konsumen mencoba untuk membandingkan antara pelayanan yang dipersiapkan (the perceived service) dengan pelayanan yang diharapkan (the expected service), Bilamana pelayanan yang dipersepsikan atau yang diperoleh berada di bawah pelayanan yang 
diharapkan, maka konsumen menjadi kecewa. Bilamana pelayanan yang dipersepsikan sama atau bahkan melebihi pelayanan yang mereka harapkan konsumen cenderung untuk menjadi puas. Oleh karena itu, perusahaan berusaha untuk menambahkan manfaat dari tawaran mereka sehingga tidak saja mampu memberikan kepuasan kepada konsumen, tapi juga akan berusaha memberikan kejutan sehinggakonsumen menjadi sangat puas.

Selain dengan kualitas pelayanan yang baik, harga juga merupakan salah satu faktor penting dalam penjualan. Harga yang ditetapkan harus sesuai dengan perekonomian konsumen, agar konsumen dapat membeli barang tersebut. Harga memainkan peranan penting dalam bauran pemasaran, karena penentuan harga terkait langsung nantinya dengan pendapatan yang diterima oleh perusahaan (Lupiyoadi, 2013:136). Hal ini merupakan salah satu faktor yang kurang diperhatikan oleh perusahaan, sehingga konsumen akan berpikir lagi untuk menggunakan produk tersebut dan akan merasa tidak puas setelah membeli atau menggunakan barang atau jasa tersebut. Sedangkan kualitas produk adalah faktor yang tak kalah penting bahwa produk makanan yang enak dengan harga terjangkau pasti akan memiliki banyak peminat. Sebaliknya, apabila harga yang ditawarkan tidak sesuai dengan produknya, maka konsumen akan berpikir dua kali untuk membeli produk pada kesempatan lain.

Salah satu jenis bisnis yang sedang marak beberapa tahun belakangan ini adalah usaha cafe. Dunia cafe tidak pernah berhenti, melainkan terus mengikuti perkembangan jaman. Suasana cafe merupakan salah satu faktor penunjang bisnis cafe dimana suasana yang tercipta dapat membuat konsumen merasakan sesuatu yang berbeda disetiap cafe yang mereka datangi. Suasana cafe yang tercipta dengan desain interior maupun eksterior, suara gemuruh/tenang, musik, penerangan dan segala sesuatu yang akhirnya membentuk perasaan nyaman atau kecewa yang dapat dirasakan oleh konsumen.

Kota Palu merupakan sentral perekonomian yang menunjukkan persaingan setiap perusahaan sangat ketat, salah satunya persaingan dalam bidang bisnis cafe. Eksistensi cafe di Kota Palu, telah menjadi pemandangan sehari-hari khususnya dikalangan masyarakat Kota Palu. Beragam nama cafe dan jenis makanan, minuman yang ditawarkan dari yang tradisional hingga modern, dan hal inilah yang terjadi di era baru generasi cafe, tidak bisa dipungkiri kehidupan masyarakat Kota Palu yang tidak terlepas dari kehidupan malamnya baik dari bersantai, tempat bertemunya rekan kerja atau teman, dan lain sebagainya yang semua membentuk menjadi satu komunitas dan menjadi perwujudan budaya modernisasi.

J.CO Donuts dan Coffe Kota Palu merupakan cafe yang cukup dikenal sebagai tempat bersantai dengan suasana yang nyaman serta bangunan yang terletak di Grand Mall Palu. J.CO Donuts dan Coffe merupakan salah satu Cafe yang menyediakan minuman jenis Coffe,serta menyediakan jenis donutsyang menjadi ciri khas utamanya.J.CO Donuts dan Coffe memiliki variasi maupun cita rasa yang berbeda-beda untuk setiap donuts yang dipasarkannya .

Berdasarkan hasil wawancara yang dilakukan kepada beberapa konsumen juga ada yang mengatakan, bahwa mereka terkadang datang pada J.CO Donuts dan Coffe hanya khusus melakukan pembelian J.CO Donuts dan Coffe.Padahal di Kota Palu selain J.CO Donuts dan Coffe juga terdapat banyak jenis usaha atau cafeyang menawarkan produk atau donuts yang sama dengan tempat yang strategsi maupun harga lebih murah, dibandingkan dengan produkyang ditawarkan oleh J.CO Donuts dan Coffe tersebut.Adapun daftar harga J.CO Donutsdan Coffe tersebut dapat dilihat pada Tabel 1 berikut ini:

Tabel 1

Daftar Harga Menu J.CO Donuts

\begin{tabular}{|c|l|l|}
\hline No. & \multicolumn{1}{|c|}{ Nama Menu } & \multicolumn{1}{c|}{ Harga } \\
\hline 1 & \multirow{2}{*}{ Donuts } & $\operatorname{Rp~8.000/Picis~}$ \\
\cline { 3 - 3 } & & $\operatorname{Rp} 47.0001 / 2$ Dozen (Stengah Lusin) \\
\cline { 3 - 4 } & & $\operatorname{Rp~84.000~1~Dozen~(Satu~Lusin)~}$ \\
\hline 2 & Baby Donuts & $\operatorname{Rp~49.000~Per~Box~(24~Buah)~}$ \\
\hline 3 & Minuman Uno & $\operatorname{Rp~32.000/Cup~Kecil~}$ \\
\hline
\end{tabular}




\begin{tabular}{|l|l|l|}
\hline & $\mathrm{Rp} 38.000 /$ Cup Medium (Sedang) \\
\cline { 3 - 3 } & $\mathrm{Rp} 42.000 /$ Cup Large (Besar) \\
\hline
\end{tabular}

Sumber: J.CO Donuts dan Coffe Palu Grand Mall, 2018

Berdasarkan tabel 1 di atas, dapat dilihat bahwa harga J.CO Donuts dan Coffe sangat beragam. Dapat dilihat dari bentuk penawaran yang diberikan saat pembelian, yaitu mulai dari per picis (perbuah), stengah lusin, serta perlusin.Dimana tentunya saat melakukan pembelian perpicis harganya tergolong lebih mahal, sedangkan pembelian stengah lusin atau satu lusin harganya dapat lebih murah.

\section{KAJIAN LITERATUR DAN PENGEMBANGANNYA}

Pemasaran merupakan salah satu faktor yang terpenting untuk memajukan perusahaan khususnya perusahaan yang bergerak dalam bidang barang dan jasa. Kesuksesan perusahaan banyak di tentukan oleh prestasi di bidang pemasaran. Pemasaran merupakan proses mempelajari kebutuhan dan keinginan konsumen dan memuaskan konsumen dengan produk dan pelayanan yang baik. Aktivitas pemasaran sering di artikan sebagai aktivitas menawarkan produk dan menjual produk, tapi bila ditinjau lebih lanjut ternyata makna pemasaran bukan hanya sekedar menawarkan atau menjual produk saja, melainkan aktivitas yang menganalisa dan mengevaluasi tentang kebutuhan dan keinginan konsumen.Seiring berjalannya waktu,masyarakat ikut berkembang, tidak hanya berkembang dalam tingkatan pendidikan,teknologi,dan gaya hidup, masyarakatpun ikut berkembang. Menurut Kotler dan Keller (2009:5) Pemasaran adalah sebuah proses kemasyarakatan dimana individu dan kelompok memperoleh apa yang mereka butuhkan dan inginkan dengan menciptakan, menawarkan, dan secara bebas mempertukarkan produk dan jasa yang bernilai dengan orang lain.

Para pemasar dapat harus memahami mengapa dan bagaimana konsumen mengambil keputusan konsumsi, sehingga pemasar dapat merancang strategi pemasaran dengan lebih baik. Selain itu, para pemasar harus mampu memahami konsumen, dan berusaha mempelajari bagaimana mereka berperilaku, bertindak dan berpikir. Walaupun konsumen memiliki berbagai macam perbedaan namun mereka juga memiliki banyak kesamaan. Para pemasar wajib memaham keragaman dan kesamaan konsumen atau perilaku konsumen agar mereka mampu memasarkan produknya dengan baik. Para pemasar dapat harus memahami mengapa dan bagaimana konsumen mengambil keputusan konsumsi, sehingga pemasar dapat merancang strategi pemasaran dengan lebih baik. Pemasar yang mengerti perilaku konsumen akan mampu memperkirakan bagaimana kecenderungan konsumen untuk bereaksi terhadap informasi yang diterimanya, sehingga pemasar dapat menyusun strategi pemasaran yang sesuai. Perilaku konsumen dapat didefinisikan kegiatan-kegiatan individu yang secara langsung terlibat dalam mendapatkan dan mempergunakan barang-barang atau jasa termasuk didalamnya proses pengambilan keputusan pada persiapan dalam penentuan kegiatan-kegiatan tersebut (Sunyoto, 2015:251)

Pelayanan kepada konsumen merupakan salah satu unsur terpenting dalam komunikasi pemasaran.Pelayanan kepada konsumen bertujuan memelihara dan meningkatkan hubungan psikologis antara produsen dan konsumen serta memantau berbagai keluhan konsumen.Pelayanan merupakan hal yang penting dalam usaha untuk membuat konsumen tetap merasa nyaman dan betah dalam menggunakan jasa dari suatu perusahaan, jika perusahaan memberikan pelayanan yang baik maka konsumen tidak akan menjauh dan menggunakan jasa dari perusahaan lain.Karena dengan pelayanan konsumen akan menilai kemudian menimbang apakah selanjutnya dia akan loyal kepada pemberi layanan tersebut. Menurut Majid (2009:35), Pelayanan adalah suatu tindakan nyata dan segera untuk menolongorang lain (pelanggan, mitra kerja, mitra bisnis, dan sebagainya), disertai dengan senyuman yang ramah dan tulus.

Kualitas pelayanan memberikan suatu dorongan kepada konsumen untuk menjalin ikatan hubungan yang kuat dengan lembaga atau instansi pemberi pelayanan jasa. Ikatan hubungan yang baik ini akan memungkinkan lembaga pelayanan jasa untuk memahami dengan seksama harapan pelanggan/pengunjung serta ke butuhan mereka. Penyedia layanan jasa dengan demikian dapat meningkatkan kepuasan pengunjung dengan memaksimalkan pengalaman pengunjung yang menyenangkan dan meminimumkan pengalaman pengunjung yang kurang menyenangkan. Kualitas 
pelayanan menurut Tjiptono (2012:59) adalah tingkat keunggulan yang diharapkan dan pengendaliannya atas tingkat keunggulan tersebut untuk memenuhi keinginan pelanggan. Terdapat faktor utama yang mempengaruhi kualitas pelayanan, yaitu bukti fisik, empati, kehandalan, daya tanggap, dan jaminan.

Perusahaan harus mempunyai strategi dalam memasarkan setiap produknya kepasaran sehingga dapat memenangkan sebuah persaingan dengan perusahaan lainnya. Misalnya membuat strategi bauran pemasaran yang akan memberikan gambaran mengenai langkah-langkah apa yang harus dilakukan oleh suatu perusahaan agar tetap dapat eksis dan bertahan ditengah persaingan yang semakin ketat. Strategi pemasaran adalah himpunan asas yang secara tepat, konsisten, dan layak dilaksanakan oleh para perusahaan guna mencapai sasaran pasar yang dituju dalam jangka panjang maupun dalam situasi persaingan tertentu. Bauran pemasaran (marketing mix) adalah kumpulan alat pemasaran taktis terkendali yang dipadukan perusahaan untuk menghasilkan respons yang diinginkannya dipasar sasaran. Bauran pemasaran terdiri dari semua hal yang dapat dilakukan perusahaan untuk mempengaruhi permintaan produknya. Bauran pemasaran juga terdiri dari $4 \mathrm{p}$, yaitu sebagai berikut (Kotler dan Amstrong, 2008: 62):

a. Produk meliputi kombinasi barang dan jasa yang ditawarkan perusahaan kepada pasar sasaran.

b. Harga meliputi jumlah uang yang harus dibayarkan pelanggan untuk memperoleh produk.

c. Tempat meliputi kegiatan perusahaan yang membuat produk tersedia bagi pelanggan sasaran.

d. Harga meliputi aktivitas yang menyampaikan manfaat produk dan membujuk pelanggan membelinya

Harga merupakan kecenderungan konsumen untuk menggunakan harga dalam memberi penilaian tentang kesesuaian manfaat produk. Penilaian terhadap harga pada suatu manfaat produk dikatakan mahal, murah atau sedang dari masing-masing individu tidaklah sama, karena tergantung dari individu yang dilatarbelakangi oleh lingkungan dan kondisi individu itu sendiri. Pada dasarnya konsumen dalam menilai harga suatu produk tidak tergantung hanya dari nilai nominal harga saja namun dari persepsi mereka pada harga. Menurut Fadil dan Priyo (2015:140) Harga adalah besaran yang di bayar oleh konsumen untuk mendapatkan produk atau jasa yang dijual oleh bisnis anda.

Kegiatan pemasaran didalamnya sangat penting untuk mengetahui keputusan pembelian yang dilakukan konsumen, karena ini akan memberikan suatu tolak ukur kepada perusahaan untuk mengetahui peluang pemasaran dalam mengatasi keputusan yang dilakukan oleh konsumen. Di tengah persaingan yang begitu ketat, perusahaan harus tahu persis akan mati muda apabila ditinggal oleh konsumennya. Sehingga setiap perusahaan dituntut harus aktif dalam proses keputusan yang dilakukan oleh konsumen, hal ini dikarenakan konsumen merupakan sebagai pengambil keputusan pembelian. Oleh karena itu agar perusahaan tersebut dapat tetap bertahan, maka perusahaan tersebut perlu mengetahui proses pengambilan keputusan pembelian yang dilakukan oleh konsumen, yaitu dimulai dengan pengenalan kebutuhan, pencarian informasi, evaluasi alternatif, keputusan pembelian, dan perilaku pasca pembelian.

Persaingan merupakan sesuatu yang tidak dapat dihindari oleh para pelaku bisnis, baik yang bergerak dibidang industri barang maupun jasa. Peningkatan kepuasan konsumen akan mempengaruhi kepercayaan terhadap pemanfaatan layanan yang di tawarkan oleh penyedia jasa. Setiap perusahaan akan berusaha untuk memberikan kepuasan untuk konsumennya. Kepuasan yang dicapai oleh konsumen akan berdampak positif kepada perusahaan karena dengan adanya kepuasan tersebut diharapkan konsumen akan melakukan pembelian kembali yang nantinya akan mempengaruhi pendapatan yang diperoleh perusahaan. Kepuasan yang tinggi atau kesenangan cenderung akan menyebabkan konsumen berperilaku positif, terjadinya kelekatan emosional terhadap merek, dan juga preferensi rasional sehingga hasilnya adalah kesetiaan (loyalitas) konsumen yang tinggi. Saat ini banyak bisnis jasa yang mulai memperhatikan kualitas layanan. Dengan adanya service quality maka kualitas layanan dapat dipantau dan disesuaikan dengan yang diharapkan oleh konsumen.Selain itu, dalam usaha menghadapi persaingan, perusahaan harus memiliki strategi yang lebih baik dibanding pesaing yang ada. Kotler dan Keller (2009:138) mendefiniskan Kepuasan sebagai perasaan senang atau kecewa seseorang yang timbul karena membandingkan kinerja yang telah dipersepsikan produk (atau hasil) terhadap ekspektasi mereka. 


\section{Kerangka Pemikiran}

Suatu perusahaan yang menginginkan agar usahanya dapat beroperasi secara terus menerus harus mampu memberikan kepuasan terhadap konsumennya. Kepuasan konsumen merupakan perbandingan antara kenyataan yang dirasakan dengan apa yang diharapkan konsumen. Kepuasan konsumen banyak dipengaruhi oleh beberapa faktor, diantaranya adalah kualitas layanan dan harga. Berdasarkan pemaparan tersebut maka kerangka pemikiran seperti pada gambar 1, berikut ini:

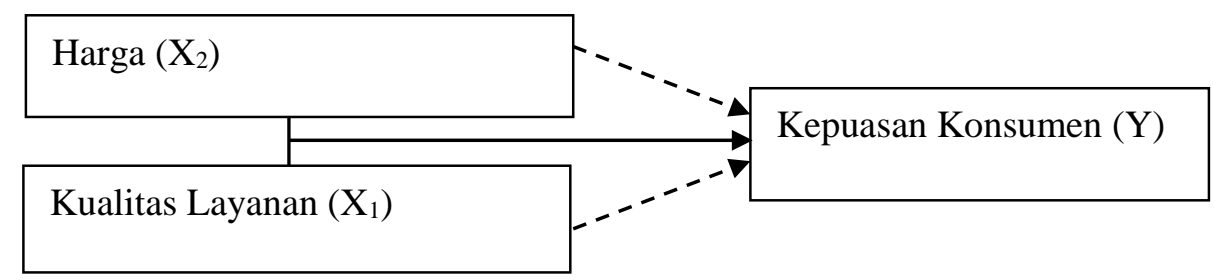

\section{Keterangan:}

\section{Gambar 1 Kerangka Pemikiran}

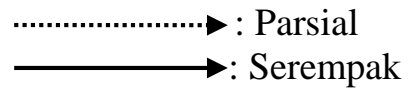

\section{Hipotesis}

$\mathrm{H}_{1}$ : Kualitas layanan dan harga secara serempak berpengaruh siginifikan terhadap kepuasan konsumen di J.CO Donuts dan Coffe Palu Grand Mall.

$\mathrm{H}_{2}$ : Kualitas layanan berpengaruh signifikan terhadap kepuasan konsumen di J.CO Donuts dan Coffe Palu Grand Mall.

$\mathrm{H}_{3}$ : Harga berpengaruh signifikan terhadap kepuasan konsumen di J.CO Donuts dan Coffe Palu Grand Mall.

\section{METODE PENELITIAN}

Jenis penelitian yang digunakan yaitu bersifat deskriptif kausal. Metode riset deskriptif bertujuan untuk menjawab pertanyaan menyangkut sesuatu pada waktu berlangsungnya riset. Penelitian kausal adalah penelitian untuk menguji hubungan kausalitas antara variabel yang dihipotesakan. Hipotesis ini sendiri menggambarkan hubungan antara dua atau lebih variabel untuk mengetahui apakah suatu variabel berasosiasi atau tidak dengan variabel lainnya.

Penelitian ini dilakukan di J.CO Donuts dan Coffe Palu Grand Mall yang beralamat di Jl. Diponegoro, Lere, Palu Barat Kota Palu, Sulawesi Tengah. Dengan alasan yaitu banyaknya konsumen yang berkunjung serta melakukan pembelian di J.CO Donuts dan Coffe Palu Grand Mall. Dalam penelitian ini, populasi adalah seluruh konsumen yang melakukan pembelian J.CO Donuts dan Coffe Palu Grand Mall. Penelitian ini menggunakan pendekatan atau teori Roscoe (dalam Sugiyono, 2010:130) karena banyaknya konsumen tidak diketahui menyatakan bahwa bila dalam penelitian akan melakukan analisis dengan multivariate, maka jumlah anggota sampel minimal 10 kali dari jumlah variabel yang diteliti. Jumlah variabel yang terdapat pada dalam penelitian ini 3 yang terdiri dari 2 variabel independen dan 1 variabel dependen. 2 variabel independen yaitu kualitas pelayanan dan harga, sedangkan 1 variabel dependen yaitu kepuasan konsumen. Berdasarkan pertimbangan tersebut maka penulis menetapkan jumlah sampel dengan ketentuan $20 \times 3$ variabel yaitu 60 responden karena mengingat bahwa jika mengambil jumlah minimum 10 saja ketelitian sampel bisa kurang baik sehingga peneliti menambah 10 lagi untuk mengurangi kesalahan dalam penelitian.

Kuesioner dalam penelitian ini telah di uji pada 20 responden diluar tempat penelitian untuk mengetahui apakah kuesioner yang nantinya akan disebar kepada konsumen di J.CO Donuts and 
Caffe layak atau tidak untuk digunakan dalam penelitian. Uji instrumen dalam penelitian dilakukan dengan menggunakan uji validitas dan uji reliabilitas sebagai berikut:

1. Uji validitas, uji validitas menurut Ghozali (2013:52) digunakan untuk mengukur sah atau valid tidaknya suatu kuesioner, suatu kuesioner dikatakan valid jika pertanyaan atau pernyataan pada kuesioner mampu untuk mengungkapkan sesuatu yang akan diukur oleh kuesioner tersebut. Syarat minimum untuk dianggap memenuhi syarat seperti dibawah ini dengan $r=0,3$. Berikut adalah tabel 2 hasil uji validitas:

Tabel 2. Hasil Uji Validitas

\begin{tabular}{|c|c|c|c|}
\hline Variabel & $\begin{array}{c}\text { Item } \\
\text { Pernyataan }\end{array}$ & $\begin{array}{l}\text { Corrected Item- } \\
\text { Total Correlation }\end{array}$ & Ket \\
\hline \multirow{10}{*}{$\begin{array}{c}\text { Kualitas } \\
\text { Layanan }\left(\mathrm{X}_{1}\right)\end{array}$} & $\mathrm{X}_{1.1}$ & .727 & Valid \\
\hline & $X_{1.2}$ & .545 & Valid \\
\hline & $\mathrm{X}_{1.3}$ & .449 & Valid \\
\hline & $\mathrm{X}_{1.4}$ & .560 & Valid \\
\hline & $\mathrm{X}_{1.5}$ & .687 & Valid \\
\hline & $\mathrm{X}_{1.6}$ & .734 & valid \\
\hline & $X_{1.7}$ & .699 & Valid \\
\hline & $\mathrm{X}_{1.8}$ & .727 & Valid \\
\hline & $\mathrm{X}_{1.9}$ & .555 & Valid \\
\hline & $\mathrm{X}_{1 \cdot 10}$ & .490 & Valid \\
\hline \multirow[t]{8}{*}{$\operatorname{Harga}\left(\mathrm{X}_{2}\right)$} & $X_{2.1}$ & .670 & Valid \\
\hline & $X_{2 \cdot 2}$ & .485 & valid \\
\hline & $\mathrm{X}_{2.3}$ & .746 & Valid \\
\hline & $\mathrm{X}_{2.4}$ & .565 & Valid \\
\hline & $\mathrm{X}_{2.5}$ & .808 & Valid \\
\hline & $\mathrm{X}_{2.6}$ & .807 & Valid \\
\hline & $\mathrm{X}_{2.7}$ & .673 & Valid \\
\hline & $\mathrm{X}_{2 \cdot 8}$ & .830 & Valid \\
\hline \multirow{4}{*}{$\begin{array}{l}\text { Kepuasan } \\
\text { Konsumen } \\
\text { (Y) }\end{array}$} & $\mathrm{Y}_{1}$ & .489 & Valid \\
\hline & $Y_{2}$ & .557 & Valid \\
\hline & $\mathrm{Y}_{3}$ & .361 & Valid \\
\hline & $\mathrm{Y}_{4}$ & .619 & Valid \\
\hline
\end{tabular}

Sumber: Data diolah Tahun 2018

Berdasarkan tabel 2 diatas diperoleh bahwa uji validitas terhadap variabel independen yang terdiri dari Kualitas Layanan $\left(\mathrm{X}_{1}\right)$ dan Harga $\left(\mathrm{X}_{2}\right)$ menunjukan nilai koefisien korelasi yang $\geq 0,30$. Sedangkan untuk variabel dependennya yaitu Kepuasan Konsumen juga menunjukan nilai koefisien korelasi yang $\geq 0,30$. Sehingga seluruh item pernyataan yang ada valid untuk digunakan.

2. Uji Reliabilitas, uji reliabilitas menurut Ghozali (2013:47) adalah alat untuk mengukur suatu kuesioner yang merupakan indikator dari variabel atau konstruk. Suatu kuesioner dikatakan reliabel atau handal jika jawaban seseorang terhadap pertanyaan adalah konsisten atau stabil dari waktu ke waktu. Peneliti mengukur reliabelnya suatu variabel dengan cara melihat Cronbach Alpha dengan signifikansi yang digunakan $>0.60$. Suatu konstruk atau variabel dikatakan reliabel jika memberikan nilai Cronbach Alpha > 0.60 (Ghozali, 2013: 48). Berikut adalah tabel 3 yaitu hasil uji realibilitas:

Tabel 3. Hasil Uji Realibilitas 


\begin{tabular}{|c|l|c|c|c|}
\hline No & \multicolumn{1}{|c|}{ Variabel Penelitian } & $\begin{array}{c}\text { Alpha } \\
\text { Cronbach's }\end{array}$ & $\begin{array}{c}\text { Alpha } \\
\text { Toleransi }\end{array}$ & $\begin{array}{c}\text { Status } \\
\text { Item }\end{array}$ \\
\hline 1 & Kualitas Layanan $\left(\mathrm{X}_{1}\right)$ & .885 & $>0.6$ & Reliabel \\
\hline 2 & Harga $\left(\mathrm{X}_{2}\right)$ & .905 & $>0.6$ & Reliabel \\
\hline 3 & Kepuasan Konsumen $(\mathrm{Y})$ & .711 & $>0.6$ & Reliabel \\
\hline
\end{tabular}

Sumber: Data diolah Tahun 2018

Berdasarkan tabel 3 diatas dapat dilihat uji realibilitas seluruh variabel baik independen maupun dependen memiliki koefisien Cronbach Alpha (a) > 0,60 sehingga berdasarkan syarat minimum reliabilitas lebih besar dari 0,60 maka seluruh variabel yang digunakan reliabel dan dapat digunakan dalam penelitian ini.

Setelah data terkumpul, maka langkah berikutnya dalam penelitian ini adalah analisis data. Tujuan analisis ini adalah untuk menginterpetasikan dan menarik kesimpulan dari sejumlah data yang terkumpul. Metode analisis data dalam penelitian ini menggunakan regresi yang akan diolah menggunakan software SPSS (Statistical Package for Social Science).

Penggunaan model analisis regresi berganda terikat dengan sejumlah asumsi dan harus memenuhi asumsi-asumsi klasik yang mendasari model tersebut. Pengujian asumsi yang harus dipenuhi syaratsyarat agar persamaan regresi dapat digunakan dengan baik (uji persyaratan analisis). Berikut adalah beberapa pengujian asumsi klasik dalam penelitian ini:

1. Uji normalitas, uji normalitas digunakan untuk menguji apakah dalam sebuah model regresi variabel (pengganggu) dependen dan independen atau keduanya memiliki distribusi normal (Ghozali, 2013:160). Model regresi yang baik adalah distribusi data normal atau mendekati normal. Deteksi normalitas dilakukan dengan melihat penyebaran data (titik) pada sumbu diagonal dan grafik.

2. Uji Multikolinieritas, uji multikolinieritas digunakan untuk menguji apakah model regresi ditemukan adanya kolerasi antara variabel bebas independen. Model regresi yang baik seharusnya antara variabel independen tidak terjadi korelasi antara variabel independen (Ghozali, 2013:105).

3. Uji Heteroskedastisitas, uji heteroskedastisitas menurut Ghozali (2013:139) uji heteroskedastisitas yaitu untuk menguji apakah dalam model regresi terjadi ketidaksamaan variance dari residual satu pengamatan ke pengamatan yang lain. Jika variance dari residual satu pengamatan ke pengamatan lain tetap, maka disebut homoskedastisitas dan jika berbeda disebut heteroskedastisitas Model regresi yang baik adalah tidak terjadi heteroskedastisitas.

Analisis data statistiknya menggunakan analisis regresi, Teknik analisis regresi yang digunakan adalah analisis regresi berganda. Analisis ini digunakan untuk mengetahui ada tidaknya pengaruh antara variabel independen $(\mathrm{X})$ terhadap variabel dependen $(\mathrm{Y})$, yakni pengaruh Kualitas Layanan $\left(\mathrm{X}_{1}\right)$ dan Harga $\left(\mathrm{X}_{2}\right)$ terhadap Kualitas Layanan untuk membeli $(\mathrm{Y})$. Selain itu, analisis regresi sangat baik digunakan untuk mengetahui kecenderungan perubahan satu variabel yang dapat mempengaruhi variabel lainnya. Berikut adalah persamaan regresi berganda:

$$
\mathrm{Y}=\mathrm{a}+\mathrm{b} 1 \mathrm{X} 1+\mathrm{b} 2 \mathrm{X} 2+\mathrm{e}
$$

Keterangan:

$\mathbf{Y} \quad=$ Variabel terikat (variabel yang diduga)

X1 dan X2 = Variabel bebas I dan II

a $\quad$ intercept atau konstanta

b1dan b2 = koefisien regresi

e $\quad=$ term error (tingkat kesalahan)

\section{HASIL DAN PEMBAHASAN}


Penelitian ini menggunakan analisis regresi linear berganda dengan tujuan untuk menguji pengaruh Kualitas Layanan dan Harga terhadap Kualitas Layanan untuk membeli pada J.CO Donuts dan Caffe di Kota Palu baik secara serempak maupun parsial. Untuk lebih jelasnya hasil analisis regresi linear berganda dapat dilihat pada tabel 4 berikut:

\begin{tabular}{|l|c|c|}
\hline \multicolumn{2}{|c|}{ Dependen Variabel Y = Kepuasan Konsumen } \\
\hline Variabel Independen $(\mathbf{X})$ & $\mathbf{B}$ & Sig t \\
\hline $\mathrm{C}=$ Costanta & .846 & .241 \\
\hline Kualitas Layanan $\left(\mathrm{X}_{1}\right)$ & .373 & .025 \\
\hline Harga $\left(\mathrm{X}_{2}\right)$ & .434 & .003 \\
\hline Multiple $\mathrm{R}=0.550^{\mathrm{a}}$ & Sig.F $=0.000$ \\
$\mathrm{R}$ Square $\left(\mathrm{R}^{2}\right)=0.303$ & \\
\hline
\end{tabular}

Berdasarkan tabel 4 di atas, olahan data yang telah dilakukan maka dapat dibentuk persamaan regresi linear berganda melalui nilai koefisien regresi (B). Untuk lebih jelasnya bentuk persamaan tersebut, dapat dilihat bentuk penjabaran sebagai berikut:

$$
Y=0.846+0.373 X_{1}+0.434 X_{2}
$$

Berdasarkan bentuk penjabaran di atas, menunjukan bahwa variabel independen yang dianalisis yaitu variabel $\left(\mathrm{X}_{1}\right.$, dan $\left.\mathrm{X}_{2}\right)$ memberi pengaruh positif terhadap variabel dependen $(\mathrm{Y})$, yaitu kepuasan konsumen di J.CO Donuts dan Coffe Palu Grand Mall. Untuk lebih jelasnya bentuk persamaan di atas, akan di uraikan sebagai berikut:

1. Nilai konstanta pada persamaan regresi menunjukkan bahwa pada saatvariabel independen kualitas layanan $\left(\mathrm{X}_{1}\right)$, dan harga $\left(\mathrm{X}_{2}\right)$, bernilai 0 makakepuasan konsumen di J.CO Donuts dan Coffe Palu Grand Mallsebesar 0.846 atau $84.6 \%$.

2. Kualitas layanan $\left(\mathrm{X}_{1}\right)$ merupakan koefisien regresi yang menunjukkan bahwa setiap variabel kualitas layanan naik satu-satuan dengan asumsi $\left(\mathrm{X}_{2}\right)$ konstan, maka kepuasan konsumen di J.CO Donuts dan Coffe Palu Grand Mall naik sebesar 0.373.

3. Harga $\left(\mathrm{X}_{2}\right)$ merupakan koefisien regresi yang menunjukkan bahwa setiap variabel harga naik satusatuan dengan asumsi $\left(\mathrm{X}_{1}\right)$ konstan, maka kepuasan konsumen di J.CO Donuts dan Coffe Palu Grand Mall naik sebesar 0.434.

Berdasarkan Tabel rekapitulasi juga dapat dilihat pengaruh hasil uji $R$ Square $\left(\mathrm{R}^{2}\right)$ sebesar 0.303 atau 30.3\% terhadap kepuasan konsumen di J.CO Donuts dan Coffe Palu Grand Mall. Sedangkan sisanya $(100 \%-30.3 \%=69.7 \%)$, dipengaruhi oleh variabel lain yang tidak diteliti. Adapun tingkat keeratan hubungan antara variabel bebas yaitu kualitas layanan, harga terhadap variabel terikat atau kepuasan konsumen di J.CO Donuts dan Coffe Palu Grand Mall melalui nilai Multiple R sebesar 0.550 atau $55.0 \%$.

Tahap selanjutnya adalah menguji signifikan hubungan secara serempakatau uji $\mathrm{F}$ antar variabel penelitian yaitu Kualitas Layanan $\left(\mathrm{X}_{1}\right)$, Harga $\left(\mathrm{X}_{2}\right)$ terhadap keputusan pembelian (Y) yang nantinya akan membandingkan nilai $\mathrm{F}$ hitung dan $\mathrm{F}$ tabel dengan perhitungan menggunakan SPSS 16 dengan hasil sebagai berikut:

Tabel 5. Hasil Uji F (Serempak) ANOVA ${ }^{\mathrm{b}}$ ANOVA

\begin{tabular}{|l|r|r|r|c|c|}
\hline Model & Sum of Squares & Df & Mean Square & F & Sig. \\
\hline 1 Regression & 2.916 & 2 & 1.458 & 12.368 & $.000^{\mathrm{a}}$ \\
Residual & 6.720 & 57 & .118 & & \\
Total & 9.636 & 59 & & & \\
\hline
\end{tabular}

a. Predictors: (Constant), X2, X1 
ANOVA $^{b}$

\begin{tabular}{|l|r|r|r|c|c|}
\hline Model & Sum of Squares & Df & Mean Square & F & Sig. \\
\hline 1 Regression & 2.916 & 2 & 1.458 & 12.368 & $.000^{\mathrm{a}}$ \\
Residual & 6.720 & 57 & .118 & & \\
Total & 9.636 & 59 & & & \\
\hline
\end{tabular}

b. Dependent Variable: Y

Berdasarkan tabel rekapitulasi regresi linear berganda diperoleh nilai Sig F yaitu 0.000 , artinya nilai tersebut lebih kecil jika dibandingkan dengan nilai yang diisyaratkan yaitu $\alpha 0.05$. Dengan demikian dapat dinyatakan bahwa secara serempak kualitas layanan dan harga berpengaruh signifikan terhadap kepuasan konsumen di J.CO Donuts dan Coffe Palu Grand Mall

Berdasarkan tabel 4 di atas, hasil uji t atau secara parsial variabel independen $\left(X_{1}\right.$ atau $\left.X_{2}\right)$ terhadap variabel dependen (Y) dijelaskan sebagai berikut:

1. Hasil Pengujian Hipotesis 2, diperoleh nilai Sig t yaitu 0.025, artinya nilai tersebut lebih kecil jika dibandingkan dengan nilai yang diisyaratkan yaitu $\alpha 0.05$, dengan demikian dapat dinyatakan bahwa secara parsial kualitas layanan berpengaruh signifikan terhadap kepuasan konsumen di J.CO Donuts dan Coffe Palu Grand Mall.

2. Hasil Pengujian Hipotesis 3, diperoleh nilai Sig t yaitu 0.003, artinya nilai tersebut lebih kecil jika dibandingkan dengan nilai yang diisyaratkan yaitu $\alpha 0.05$, dengan demikian dapat dinyatakan bahwa secara parsial harga berpengaruh signifikan terhadap kepuasan konsumen di J.CO Donuts dan Coffe Palu Grand Mall.

\section{Pembahasan}

Berdasarkan hasil olahan data serta analisis yang telah dilakukan pada penelitian ini, membuktikan bahwa variabel kualitas layanan berpengaruh signifikanterhadap kepuasan konsumen di J.CO Donuts dan Coffe Palu Grand Mall. Kualitas pelayanan yang diberikan oleh pihak J.CO Donuts dan Coffe memberikan kesan sendiri bagi konsumen untuk datang kembali ke rumah makan tersebut. Perusahaan yang mengutamakan kualitas pelayanan yang baik akan memberikan dampak yang positif terhadap kepuasan konsumen.

Kualitas pelayanan adalah suatu tingkat keunggulan yang dirasakan seseorang terhadap suatu jasa yang diharapkan dari perbandingan antara keinginan dan kinerja yang dirasakan konsumen setelah jasa tersebut. Kualitas pelayanan dapat diketahui dengan cara membandingkan persepsi konsumen atas layanan yang benar-benar mereka terima dengan layanan sesungguhnya yang mereka harapkan. Kualitas pelayanan menjadi hal utama yang diperhatikan serius oleh perusahaan, yang melibatkan seluruh sumber daya yang dimiliki perusahaan. Kualitas pelayanan diartikan sebagai tingkat keunggulan yang diharapkan dan pengendalian atas tingkat keunggulan tersebut untuk memenuhi keinginan konsumen.

Hasil penelitian ini, juga mendukung penelitian-penelitian terdahulu, salah satunya penelitian yang dilakukan olehWindarti dan Ibrahim (2017) dengan judul penelitian Pengaruh Kualitas Produk Dan Kualitas Pelayanan Terhadap Kepuasan Konsumen Produk Donat Madu (Studi Pada Konsumen CV. Donat Madu Cihanjuang-Pekanbaru).Hasil penelitian menunjukkan bahwa kualitas layanan berpengaruh positif dan signifikan terhadap kepuasan konsumen Produk Donat Madu (Studi Pada Konsumen CV. Donat Madu Cihanjuang-Pekanbaru).

Senada dengan penelitian yang juga telah dilakukan oleh Pertiwi (2017) dengan hasil penelitian menunjukkan bahwa kualitas layanan berpengaruh signifikan terhadap kepuasan konsumen Toko Roti "Yulia Bakery" Kota Kediri. Menurut Raharjo (2015) dengan hasil penelitian yang telah dilakukan juga menunjukkan terdapat pengaruh yang positif dan signifikan antara kualitas pelayanan terhadap kepuasan pelanggan Pada J.CO Donuts dan Coffee Java Mall.

Berdasarkan hasil olahan data serta analisis yang telah dilakukan pada penelitian ini, membuktikan bahwa variabel harga berpengaruh signifikanterhadap kepuasan konsumen di J.CO Donuts dan Coffe 
Palu Grand Mall.Harga yang ditetapkan oleh di J.CO Donuts dan Coffe Palu Grand Mall sesuai dengan keadaan perekonomian masyarakat, harga dan kualitas memiliki pengaruh yang tinggi terhadap kepuasan konsumen.

Harga digunakan sebagai tolak ukur terhadap kualitas produk, yang berakibat anggapan kualitas yang lebih baik dari suatu produk dan menentukan kepuasan yang lebih tinggi, oleh sebab itu harga yang ditetapkan harus seimbang dengan kualitas yang diberikan pada konsumen.Harga merupakan salah satu faktor yang menjadi perhatian konsumen dalam membeli sesuatu. Harga yang terlalu tinggi tanpa diimbangi dengan kualitas yang baik maka dapat menimbulkan kekecewaan konsumen. Jadi pihak produsen harus pandai dalam menetapkan harga jual suatu produk.

Hasil penelitian ini, juga mendukung penelitian-penelitian terdahulu, salah satunya penelitian yang dilakukan oleh Hamdun dan Romadhani (2016) melakukan penelitian dengan judul penelitian Pengaruh Produk, Harga Dan Harga Terhadap Kepuasan Konsumen Pada Toko Roti Fatimah Bakery Di Situbondo. Hasil pengujian menunjukkan bahwa variabel harga memiliki pengaruh yang positif dan signifikan terhadap Kepuasan Konsumen Pada Toko Roti Fatimah Bakery Di Situbondo.

Senada dengan penelitian yang juga dilakukan oleh Raharjo (2015) dengan hasil penelitian menunjukkan terdapat pengaruh yang positif dan signifikan antara harga terhadap kepuasan pelanggan Pada J.CO Donuts dan Coffee Java Mall.Menurut Budiarsih (2017) dengan hasil penelitian yang telah dilakukan jugamenunjukkan bahwa harga berpengaruh signifikan terhadap kepuasan konsumen Restoran Pizza Hut Kediri.

\section{KESIMPULAN DAN SARAN}

Berdasarkan hasil analisis dan pembahasan yang telah dilakukan pada penelitian ini maka dapat ditarik beberapa kesimpulan, sebagai berikut:

1. Kualitas layanan dan harga secara serempak berpengaruh siginifikan terhadap kepuasan konsumen di J.CO Donuts dan Coffe Palu Grand Mall.

2. Kualitas layanan berpengaruh signifikan terhadap kepuasan konsumen di J.CO Donuts dan Coffe Palu Grand Mall.

3. Harga berpengaruh signifikan terhadap kepuasan konsumen di J.CO Donuts dan Coffe Palu Grand Mall.

Berdasarkan kesimpulan di atas, maka peneliti memberikan beberapa saran sebagai bahan pertimbangan, yaitu sebagai berikut:

1. Kepada J.CO Donuts dan Coffe Palu Grand Mall, dapat lebih meningkatkan variabel kualitas layanan mengenai jaminan dan empati khususnya indikator rasa donuts selalu sama, serta perhatian secara individu sehingga nantinyakonsumen dapat lebih meningkatkan pembeliannya.

2. Untuk penelitian selanjutnya diharapkan dapat mencari, menambahkan, atau mengkombinasikan variabel-variabel pembentuk kepuasan konsumen di J.CO Donuts dan Coffe Palu Grand Mall, agar hasil penelitiannya dapat memberikan kontribusi yang bermakna bagi pihak-pihak yang berkepentingan.

\section{REFERENSI}

Adisucipto, Gunawan. 2010. Manajemen Pemasaran. Yogyakarta: Unit Penerbit YKPN.

Budiarsih, Retno. 2017. Pengaruh Kualitas Pelayanan, Kualitas Produk Dan Harga Terhadap Kepuasan Konsumen Pada Restoran Pizza Hut Di Kota Kediri. Simki-Economic Vol. 01 No. 09 Tahun 2017.

Fadil, Zaki dan Priyo Utama. 2015. Teknik Marketing Itu Mudah Perencanaan Marketing Strategis Untuk Mengurus Bisnis. Yogyakarta: Second Hope.. 
Ghozali, Imam, 2013 .Aplikasi Analisis Multivariate dengan Program SPSS. Cetakan Keenam. Semarang: Badan Penerbit Universitas Diponegoro.

Hamdun, Edy Kusnadi dan Romadhani, Denok Ariestya. 2016. Pengaruh Produk, Harga Dan Promosi Terhadap Kepuasan Konsumen Pada Toko Roti Fatimah Bakery Di Situbondo. Jurnal Ekonomi dan Bisnis GROWTH Vol. 14, No. 2, November 2016:31-48.

Kotler, Philip dan Armstrong, 2008. Prinsip-prinsip Pemasaran. Terjemahan Bob Sabran, Edisi Kedua Belas, Jilid I, Ciracas, Jakarta: Erlangga.

Kotler, Philip dan Keller, 2009. Manajemen Pemasaran. Terjemahan Benyamin Molan, Edisi Ketiga Belas, Jilid I, Ciracas, Jakarta: Erlangga.

Lupiyoadi, Rambat. 2013. Manajemen Pemasaran Jasa. Jakarta: Salemba Empat.

Majid, Abdul Suharto. 2009. Customer Service Dalam Bisnis Jasa. Jakarta: Rajawali Press.

Pertiwi, Elsa Lintang. 2017. Pengaruh Kualitas Produk, Kelengkapan Produk Dan Kualitas Layanan Terhadap Kepuasan Konsumen Toko Roti "Yulia Bakery" Kota Kediri. Simki-Economic Vol. 01 No. 11 Tahun 2017.

Raharjo, Irfan Listyono. 2015. Analisis Pengaruh Harga, Kepercayaan Pelanggan, dan Kualitas Pelayanan Terhadap Loyalitas Pelanggan Melalui Kepuasan Pelanggan Pada J.CO Donuts dan Coffee Java Mall.Jurnal Vol.3 No.1 Maret 2015.

Sunyoto Danang. 2015. Perilaku Konsumen dan Pemasaran. Yogyakarta: Penerbit CAPS..

Sugiyono, 2010. Metode Penelitian Bisnis. Bandung: Penerbit Alfabeta.

Tjiptono, Fandy, 2012. Pemasaran Jasa. Yogyakarta: Andi Offset.

Windarti Tias dan Ibrahim Mariaty. 2017. Pengaruh Kualitas Produk Dan Kualitas Pelayanan Terhadap Kepuasan Konsumen Produk Donat Madu (Studi Pada Konsumen CV. Donat Madu Cihanjuang-Pekanbaru). Jom FISIP Volume 4 No. 2 Oktober 2017. 